\title{
Workplace Environment and Productivity: Employees' Reaction towards the Quality of Physical Environment in Rented Saudi Workplaces
}

\author{
Adel Mohammad A. Binyaseen \\ Department of Islamic Architecture, College of Engineering and Islamic \\ Architecture, Umm Al-Qura University, Makkah, Saudi Arabia \\ binyaseen@yahoo.com
}

(Received: 30/05/2009, Accepted: 07/10/2010)

\begin{abstract}
Research concerned with enhancing productivity in workplaces has considered physical environment as a key issue. Recent trends in workplace design always call for the need to use physical environment as a tool to encourage productivity. Due to the growing evidence which relates physical environment with productivity, this paper examines employees' satisfaction with their physical environment in five rented Saudi workplaces. The research is prompted by the need to demonstrate to Saudi governmental organizations that the existing situation of rented workplaces does not provide employees with enough support to perform their jobs effectively. Results out of five rented workplaces belonging to Municipality of Makkah revealed some dissatisfaction of different staff groups with nine important aspects of physical environment in workplaces. Satisfaction with Privacy, services and workspace area were found to be the strongest predictors of overall workplace satisfaction (OWS). Moreover, employees considered satisfaction with these predictors as important factors to achieve productivity.
\end{abstract}

Keywords: Workplace, Organization, Productivity, Privacy, Workspace, Satisfaction, Physical environment.

\section{Introduction}

Organization structure and culture have a direct impact on shaping the physical settings of workplaces ${ }^{[1]}$. Early research tried to link 
organization theory with office layouts ${ }^{[2]}$. Thus, any changes in organizational structure is expected to cause a change in the physical settings of the workplace. The Sun Microsystems company experienced in calling for more decentralization in work transactions has led the company to choose the nonterritorial corporate office looking for a mix of unassigned desks, private offices, common areas, and widely accessible computer network. The approach witnessed decrease in personal space balanced by an increase in common space, with a focus on multiple level of interaction ${ }^{[3]}$.

New trends in office design have considered physical environment in workplaces as a means not only to bring delights and happiness to employees, but also to support creativity and increase productivity. Kovel Kresser \& Partners converted an old construction in California into a creative work space design looking for creating a workplace that supports creativity and improves staff performance ${ }^{[4]}$. A preview of trends in corporate office design in Southern California in 2005 has found that companies used physical design by providing all the necessary elements to attract and retain high-caliber employees and increase productivity, including comfort, flexibility, and security ${ }^{[5]}$.

Former trends in office design are concerned with the comfort of higher employees only. Organizations have realized nowadays the significance of comfort in the workplace environment in order to retain quality employees and boost productivity. Physical environment issues of materials, color, furniture, lighting, and space planning have direct impact on employees comfort ${ }^{[6]}$. The composition of the workspace unit has also been related to staff comfort and productivity. Adjusting desks and accessories not only relieve physical aches and pains for employees, but also help to alleviate management concerns about low productivity ${ }^{[7]}$.

Genzyme Center in Cambridge, Massachuetts, as one of just 32 platinum LEED-certified buildings in USA has attracted huge number of visitors due to its supergreen design. The strategic goal of the organization is to keep its employees happy, healthy, and working hard ${ }^{[8]}$. Sterk has also called for the need to design the work environment for maximum worker satisfaction for better productivity ${ }^{[9]}$.

Pam Brenner, the manager of workplace issues at Steelecase Inc., determined office space to play a major part in efficiency. He has also described privacy as a key issue, and a lack of it can inhibit employees 
from accomplishing their work effectively ${ }^{[10]}$. Kupritz has also found that enough work space, services including equipments, and privacy are the most productivity-aiding factors in workplace ${ }^{[11]}$.

Thus, the connection between the importance of physical environment in workplaces and employees' satisfaction is well established in the literature. The ability of physical environment to bring happiness and delight to employees has been widely considered by big organizations. Moreover, smart organizations have used physical environment as a tool to attract their employees.

\section{Research Problem and Methodology}

Due to the growing evidence which relates workplace environment to employees comfort and productivity, this paper examines the situation of workplace environment in some rented governmental workplaces in Saudi Arabia. Governmental organizations are unaware of employees' reactions towards their physical environment in these rented workplaces. The paper claims that the workplace environment in these rented buildings does not match the employees' expectation, causing dissatisfaction among staff, leading to hampering productivity.

Five rented branch buildings belonging to the Municipality of Makkah scattered in different parts of the city were selected. These are rented non-purposed buildings which consist of conventional rooms and were designed basically for residential purpose. Employees occupy these rooms in a minimum of double occupancy except for managers. Room size varies from 20-60 square meters. Workspaces were located in corners with no partitions or panel systems. Common spaces in these buildings were found in some rooms assigned as praying area or cafeteria.

Many people complain about the quality and level of services provided by these branch buildings. Employees admitted that the poor workplace environment condition has affected their performance badly. A questionnaire has been administered to cover at least $50 \%$ of the staff . Three groups of staff were selected. These are secretaries, administrators, and managers. Table 1 shows numbers of staff groups participated in the study. 
Table 1 .Names of branch Municipality buildings and number of incorporated staff groups.

\begin{tabular}{|c|c|c|c|c|c|c|c|}
\hline \multirow{3}{*}{$\begin{array}{l}\text { Name of building: } \\
\text { Makkah branch } \\
\text { Municipality }\end{array}$} & \multicolumn{7}{|c|}{ Number of staff } \\
\hline & \multicolumn{2}{|c|}{$\begin{array}{c}\text { Secretaries } \\
\mathrm{S}\end{array}$} & \multicolumn{2}{|c|}{$\begin{array}{c}\text { Administrators } \\
\text { A }\end{array}$} & \multicolumn{2}{|c|}{$\begin{array}{c}\text { Managers } \\
\mathbf{M} \\
\end{array}$} & \multirow{2}{*}{$\begin{array}{l}\text { Total } \\
100 \%\end{array}$} \\
\hline & No. & $\%$ & No. & $\%$ & No. & $\%$ & \\
\hline 1-Ajyad & 10 & 33.3 & 14 & 46.7 & 6 & 20.0 & 30 \\
\hline 2-Mabedah & 4 & 15.4 & 16 & 61.5 & 6 & 23.0 & 26 \\
\hline 3-Aziziah & 8 & 28.6 & 14 & 50.0 & 6 & 21.4 & 28 \\
\hline 4-Shoqiah & 12 & 37.5 & 16 & 50.0 & 4 & 12.5 & 32 \\
\hline 5-Masfalah & 12 & 40.0 & 16 & 53.3 & 2 & 6.70 & 30 \\
\hline
\end{tabular}

$\mathrm{S}=$ Secretaries $\quad \mathrm{A}=$ Administrators $\quad \mathrm{M}=$ Managers

Staff were asked to determine their level of satisfaction with nine aspects of workplace environment. These are satisfaction with workspace area, privacy, natural lighting, noise level, air conditioning, parking, quality of services, proximity with co-workers, and opportunity of informal meetings with co-workers. Workspace area is defined as the number of square meters designated for each employee. Services included W.C., cafeteria, praying area, and necessary equipments. Employees were also asked to determine the importance of satisfaction with aspects of workplace environment on their level of productivity. Both age and sex were also considered.

Several variables were also developed. These include office area which refers to actual room area. Status refers to the three groups of staff according to their rank in organization. Staff/room refers to the number of staff in each room. Staff/W.C. refers to number of staff assigned per each W.C. unit. Area/staff refers to the number of square meters for each employee on building scale. Area/prayer refers to assigned square meters for each prayer. Parking/staff refers to staff-parking ratio.

\section{Results and Discussions}

Employee's reaction towards their level of satisfaction with nine aspects of physical environment was developed. These include satisfaction with workspace area, privacy, natural lighting, noise level, air conditioning, parking, quality of services, proximity with co-workers, and opportunity of informal meetings with co-workers. 
Tables $2 \& 3$ show level of employees' satisfaction with the adopted physical environment aspects among the three staff groups. Employees who witnessed a score less than 3 were considered to be dissatisfied. The dissatisfaction with the adopted aspects of physical environment among the three groups varies dramatically. The degree of dissatisfaction among the adopted cases was noticed to be as follows:

1- Dissatisfaction with the quality of services especially among secretaries. The situation is worse in buildings 3,5 and 1 respectively.

2- Dissatisfaction with the level of noise among secretaries in all buildings except building 2. Secretaries in Buildings 1,5\&4 experienced the highest level of dissatisfaction respectively.

3- Dissatisfaction with parking spaces has been noticed in buildings $1 \& 5$ among all staff groups.

4- Dissatisfaction with the level of informal meetings with coworkers in building $3 \& 1$.

5- Dissatisfaction with the level of privacy especially among administrators in buildings $1,5 \& 4$.

6- Dissatisfaction with the quality of air conditioning in buildings $5,3 \& 1$ among different groups.

7- Dissatisfaction with proximity to co-workers in building 3 among all staff groups.

8- Dissatisfaction with workspace area among administrators in building $1 \& 4$.

9- Employees in building $1 \& 5$ were the most dissatisfied, whereas they were the most satisfied in building 2 .

In general, the degree of dissatisfaction with aspects of physical environment among the three groups of staff in the five cases could be summarized in three levels. The first level is high dissatisfaction with quality of services and level of noise. The second level is medium dissatisfaction with availability of parking space and the level of informal meetings among staff. The third level is low dissatisfaction with the level of privacy, quality of air conditioning, proximity with co-workers and workspace area. 
Table 2. Level of satisfaction among the three groups of staff in a scale ranging from (1) to (5).

\begin{tabular}{|c|c|c|c|c|c|c|c|c|c|c|}
\hline B & G & $\begin{array}{c}\text { Sts. } \\
\text { A }\end{array}$ & $\begin{array}{c}\text { Sts. } \\
\text { P }\end{array}$ & $\begin{array}{l}\text { Sts. } \\
\text { NL }\end{array}$ & $\begin{array}{c}\text { Sts. } \\
\text { N }\end{array}$ & $\begin{array}{l}\text { Sta. } \\
\text { A.C. }\end{array}$ & $\begin{array}{c}\text { Sts. } \\
\text { Pk }\end{array}$ & $\begin{array}{c}\text { Sts. } \\
\text { S }\end{array}$ & $\begin{array}{l}\text { Sts. } \\
\text { Wrk }\end{array}$ & $\begin{array}{l}\text { Sts. } \\
\text { M. }\end{array}$ \\
\hline \multirow[t]{3}{*}{1} & $\mathrm{~S}$ & 2.00 & 2.00 & 4.40 & 2.00 & 2.60 & 1.60 & 2.40 & 3.80 & 3.20 \\
\hline & A & 1.14 & 1.71 & 4.00 & 2.14 & 3.14 & 1.29 & 1.86 & 3.57 & 2.14 \\
\hline & $\mathrm{M}$ & 4.00 & 3.33 & 4.33 & 2.67 & 3.33 & 2.67 & 3.00 & 4.67 & 2.00 \\
\hline \multirow[t]{3}{*}{2} & $\mathrm{~S}$ & 5.00 & 4.00 & 5.00 & 4.50 & 5.00 & 5.00 & 4.50 & 4.50 & 4.50 \\
\hline & $\mathrm{A}$ & 4.00 & 3.50 & 4.00 & 3.00 & 3.50 & 3.50 & 3.25 & 4.13 & 4.50 \\
\hline & $\mathrm{M}$ & 4.67 & 4.33 & 3.67 & 3.33 & 3.00 & 4.67 & 4.33 & 4.00 & 4.00 \\
\hline \multirow[t]{3}{*}{3} & $\mathrm{~S}$ & 4.25 & 3.25 & 4.25 & 2.75 & 4.33 & 3.75 & 1.00 & 1.89 & 1.29 \\
\hline & $\mathrm{A}$ & 3.86 & 3.43 & 4.00 & 3.00 & 2.57 & 3.71 & 0.79 & 0.38 & 0.53 \\
\hline & $\mathrm{M}$ & 4.00 & 4.67 & 5.00 & 3.33 & 4.33 & 4.67 & 1.53 & 1.15 & 0.58 \\
\hline \multirow[t]{3}{*}{4} & $\mathrm{~S}$ & 3.33 & 3.00 & 3.33 & 2.50 & 3.33 & 3.67 & 2.50 & 3.83 & 3.50 \\
\hline & A & 2.00 & 2.63 & 4.00 & 2.75 & 4.13 & 3.25 & 3.13 & 4.13 & 3.29 \\
\hline & $\mathrm{M}$ & 4.50 & 4.50 & 4.00 & 4.00 & 4.50 & 5.00 & 3.50 & 4.50 & 4.50 \\
\hline \multirow[t]{3}{*}{5} & $\mathrm{~S}$ & 3.33 & 3.17 & 3.83 & 2.33 & 3.00 & 1.83 & 2.33 & 2.67 & 2.50 \\
\hline & A & 3.25 & 2.50 & 2.88 & 2.13 & 2.50 & 2.13 & 2.50 & 4.00 & 3.13 \\
\hline & $\mathrm{M}$ & 4.00 & 4.00 & 4.00 & 3.00 & 2.00 & 2.00 & 2.00 & 4.00 & 4.00 \\
\hline
\end{tabular}

$\mathrm{B}=$ Building Number

Sts.A= Satisfaction with workspace Area

Sts. NL=Satisfaction with Natural Lighting

Sts. A.C. $=$ Satisfaction with Air conditioning

Sts. $\mathrm{S}=$ Satisfaction with Services

Sts. M.= Satisfaction with Informal Meetings.

$1=$ Very dissatisfied, $2=$ Dissatisfied, $3=$ Just satisfied, $4=$ Satisfied, $5=$ Very satisfied.

$\mathrm{S}=$ Secretaries, $\mathrm{A}=$ Administrators, $\mathrm{M}=$ Managers
$\mathrm{G}=$ Staff Groups

Sts. $\mathrm{P}=$ Satisfaction with Privacy

Sts.N= Satisfaction with Noise

Sts.Pk= Satisfaction with parking

Sts. Wrk=Satisfaction with proximity to co-worker

The high level of dissatisfaction with level of services was found in buildings that have low standards of services. In building 3 , no cafeteria or praying area were found. Other buildings have lower standards in W.C. rate, such as building 5, where it has one W.C. for every 24 staff. This has been described by staff as absolutely unbearable. Dissatisfaction with noise level was caused mainly by number of staff per room. In Building 1, the ratio reached up to 10 staff per room. This has caused continuous distraction and disturbance for staff. This crowding situation has caused dissatisfaction with privacy. The situation getting worse when visitors are available. Dissatisfaction with parking was reported due to low staff to parking spaces ratio. In building 1, no parking spaces were assigned to staff due to valuable and scarcity of land in the center of Makkah. In building 5 one parking space is assigned for every three staff. This has also been expressed by staff as unacceptable. Dissatisfaction with informal meetings among staff was due to the lack of common spaces in these building such as cafeteria and gathering areas. 
Table 3. The satisfied and dissatisfied staff groups among the five buildings.

\begin{tabular}{|c|c|c|c|c|c|c|c|c|c|c|}
\hline B & $\mathbf{S}$ & $\begin{array}{c}\text { Sts. } \\
\text { A }\end{array}$ & $\begin{array}{c}\text { Sts. } \\
\mathbf{P}\end{array}$ & $\begin{array}{l}\text { Sts. } \\
\text { NL }\end{array}$ & $\begin{array}{c}\text { Sts. } \\
\text { N }\end{array}$ & $\begin{array}{l}\text { Sts. } \\
\text { A.C. }\end{array}$ & $\begin{array}{c}\text { Sts. } \\
\text { Pk }\end{array}$ & $\begin{array}{c}\text { Sts. } \\
\text { S }\end{array}$ & $\begin{array}{c}\text { Sts. } \\
\text { Wrk }\end{array}$ & $\begin{array}{l}\text { Sts. } \\
\text { M. }\end{array}$ \\
\hline \multirow[t]{3}{*}{1} & $\mathrm{~S}$ & $\times$ & $\times$ & $\sqrt{ }$ & $\times$ & $\times$ & $\times$ & $\times$ & J & $\sqrt{ }$ \\
\hline & A & $x$ & $x$ & J & $x$ & $\sqrt{ }$ & $x$ & $x$ & J & $x$ \\
\hline & $M$ & J & J & $\checkmark$ & $x$ & J & $x$ & $\checkmark$ & $\sqrt{ }$ & $x$ \\
\hline \multirow[t]{3}{*}{2} & $\mathrm{~S}$ & $\sqrt{ }$ & J & $\sqrt{ }$ & J & J & $\sqrt{ }$ & J & $\sqrt{ }$ & $\sqrt{ }$ \\
\hline & A & J & $\sqrt{ }$ & $\sqrt{ }$ & J & $\sqrt{ }$ & $\sqrt{ }$ & J & J & $\sqrt{ }$ \\
\hline & $\mathrm{M}$ & J & $\sqrt{ }$ & $\checkmark$ & $\sqrt{ }$ & $\sqrt{ }$ & $\sqrt{ }$ & $\checkmark$ & J & J \\
\hline \multirow[t]{3}{*}{3} & $\mathrm{~S}$ & J & J & $\checkmark$ & $x$ & $\sqrt{ }$ & $\checkmark$ & $x$ & $x$ & $x$ \\
\hline & $\mathrm{A}$ & $\sqrt{ }$ & $\sqrt{ }$ & $\sqrt{ }$ & $\sqrt{ }$ & $x$ & $\sqrt{ }$ & $x$ & $x$ & $x$ \\
\hline & $\mathrm{M}$ & J & J & $\sqrt{ }$ & J & J & $\sqrt{ }$ & $x$ & $x$ & $x$ \\
\hline \multirow[t]{3}{*}{4} & $\mathrm{~S}$ & J & J & $\sqrt{ }$ & $x$ & $\sqrt{ }$ & $\sqrt{ }$ & $x$ & $\sqrt{ }$ & J \\
\hline & A & $x$ & $x$ & J & $x$ & J & 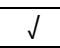 & $\checkmark$ & $\sqrt{ }$ & J \\
\hline & $\mathrm{M}$ & $\sqrt{ }$ & 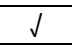 & $\sqrt{ }$ & $\sqrt{ }$ & $\sqrt{ }$ & $\sqrt{ }$ & $\sqrt{ }$ & $\sqrt{ }$ & $\sqrt{ }$ \\
\hline \multirow[t]{3}{*}{5} & $\mathrm{~S}$ & J & J & J & $x$ & J & $x$ & $x$ & $x$ & $x$ \\
\hline & $\mathrm{A}$ & $\sqrt{ }$ & $x$ & $x$ & $x$ & $x$ & $x$ & $x$ & $\sqrt{ }$ & J \\
\hline & $\mathrm{M}$ & $\sqrt{ }$ & J & $\checkmark$ & J & $x$ & $x$ & $x$ & $\sqrt{ }$ & J \\
\hline
\end{tabular}

$x=$ Dissatisfied $\quad J=$ Satisfied

The paper suggested that the situation could be improved by raising the standard of services and enhancing overall workspace criteria as much as possible. The paper will use standards that were considered by staff as satisfactory. In this respect, Secretaries should have a maximum of three per room, administrators should have a maximum of double occupancy, and managers should have single occupancy. In case of large rooms and open spaces, partitions and panels could be used to subdivide large areas. This will also contribute in decreasing the level of noise and improve level of privacy. Staff per W.C. ratio should be improved, this should be around one W.C. for every 12 staff. Common spaces such as cafeteria, praying area, gathering area have to be provided to improve level of services and give staff the opportunity of informal meeting. Parking spaces have to be also provided, a single parking space for each staff should be available, although it could be difficult for building 1 to afford that due to shortage of land in the center area.

In order to find out the strongest physical environment predictors of workplace satisfaction, overall employees' satisfaction towards their workplaces was regressed against the satisfaction of nine aspects of incorporated physical environment variables. Table 4 (a) shows that stepwise regression selected three strongest predictors of overall workplace satisfaction: satisfaction with privacy; satisfaction with services; and satisfaction with workplace area with adjusted $\mathrm{R}^{2}=76.5 \%$, 
$84.0 \%$, and $87.2 \%$ respectively. The regression is strongly valid since all predictors show significant test $(p<0.001)$.

Table 4 (a). Results of Step-wise regression showing the three strongest predictors of overall workplace satisfaction. All other variables were removed due to their intercorrelations among each other. The three predictors of satisfaction have therefore been treated as constants.

\begin{tabular}{|c|c|c|c|c|c|c|c|c|}
\hline \multirow{2}{*}{ Model } & \multirow{2}{*}{$\mathbf{R}$} & \multirow{2}{*}{$\mathbf{R}^{\mathbf{2}}$} & \multirow{2}{*}{$\begin{array}{c}\text { Adjusted } \\
\mathbf{R}^{\mathbf{2}}\end{array}$} & \multicolumn{5}{|c|}{ Change Statistics } \\
\cline { 5 - 9 } & & & $\begin{array}{c}\mathbf{R}^{\mathbf{2}} \\
\text { change }\end{array}$ & $\begin{array}{c}\mathbf{F} \\
\text { Change }\end{array}$ & $\mathbf{d f 1}$ & $\mathbf{d f 2}$ & $\begin{array}{c}\text { Sig. F } \\
\text { change }\end{array}$ \\
\hline 1 & $.876^{\mathrm{a}}$ & .768 & .765 & .768 & 225.330 & 1 & 68 & .000 \\
\hline 2 & $.919^{\mathrm{b}}$ & .845 & .840 & .077 & 33.084 & 1 & 67 & .000 \\
\hline 3 & $.937^{\mathrm{c}}$ & .878 & .872 & .033 & 17.898 & 1 & 66 & .000 \\
\hline
\end{tabular}

a- Predictor (constant): satisfaction with privacy

b- Predictor (constant): satisfaction with privacy, satisfaction with services

c- Predictor (constant): satisfaction with privacy, satisfaction with services, and satisfaction with workspace area.

From Table 4 (b), the regression equation of Overall Workplace Satisfaction (OWS) is:

OWS $=0.028+0.457$ (Sts. P.) +0.306 (Sts. S.) +0.227 (Sts. A.)

Where:

Sts. P. = Satisfaction with Privacy

Sts. S. = Satisfaction with Services

Sts. A. = Satisfaction with workspace Area.

The effect of each predictor on OWS is clearly indicated in its coefficient.

Table 4 (b). Coefficients of the regression equation. The regression equation of Overall Workplace Satisfaction.

\begin{tabular}{|l|c|c|c|c|c|}
\hline \multirow{2}{*}{ Model } & \multicolumn{2}{|c|}{$\begin{array}{c}\text { Unstandardized } \\
\text { coefficients }\end{array}$} & $\begin{array}{c}\text { Standardized } \\
\text { coefficients }\end{array}$ & \multirow{2}{*}{ t } & Sig. \\
\cline { 2 - 4 } & B & $\begin{array}{c}\text { Std. } \\
\text { Error }\end{array}$ & Beta & & \\
\hline 1-(Constant) & .784 & .170 & - & 4.605 & .000 \\
Sts. P. & .747 & .050 & .876 & 15.011 & .000 \\
\hline 2-(Constant) & .231 & .170 & - & 1.356 & .180 \\
Sts. P. & .628 & .046 & .736 & 13.654 & .000 \\
Sts. S. & .311 & .054 & .310 & 5.752 & .000 \\
\hline 3-(Constant) & .028 & .159 & - & .173 & .863 \\
Sts. P. & .457 & .058 & .536 & 7.942 & .000 \\
Sts. S. & .306 & .048 & .305 & 6.326 & .000 \\
Sts. A. & .227 & .054 & .272 & 4.231 & .000 \\
\hline
\end{tabular}

$\mathrm{OWS}=0.028+0.457$ (Sts.P.) +0.306 (Sts. S.) +0.227 (Sts. A.). 
Table 4 (c) supports the regression results, where the three strongest predictors of OWS showed significant variation among each other with $p<0.001$ and high $\mathrm{F}$ value once ANOVA test is applied.

Table 4 (c). ANOVA test for the three strongest predictors of Overall Workplace Satisfaction OWS.

\begin{tabular}{|l|l|l|c|l|c|c|}
\hline \multicolumn{2}{|c|}{ Model } & \multicolumn{1}{|c|}{$\begin{array}{c}\text { Sum of } \\
\text { Squares }\end{array}$} & df & $\begin{array}{c}\text { Mean of } \\
\text { Square }\end{array}$ & \multirow{2}{*}{ F } & \multirow{2}{*}{ Sig. } \\
\hline \multirow{2}{*}{$\begin{array}{l}\text { Satisfaction } \\
\text { with privacy }\end{array}$} & Regression & 81.657 & 1 & 81.657 & 225.330 & \multirow{2}{*}{$0.000^{\text {a }}$} \\
\cline { 2 - 5 } & Residual & 24.643 & 68 & 0.362 & & \\
\cline { 2 - 5 } & Total & 106.300 & 69 & & & \\
\hline \multirow{2}{*}{$\begin{array}{l}\text { Satisfaction } \\
\text { with services }\end{array}$} & Regression & 89.803 & 2 & 44.902 & \multirow{2}{*}{182.365} & \multirow{2}{*}{$0.000^{\text {b }}$} \\
\cline { 2 - 5 } & Residual & 16.497 & 67 & 0.246 & \\
\cline { 2 - 5 } & Total & 106.300 & 69 & & \multirow{2}{*}{$0.000^{\text {c }}$} \\
\cline { 1 - 5 } $\begin{array}{l}\text { Satisfaction } \\
\text { with workspace } \\
\text { area }\end{array}$ & Regression & 93.323 & 3 & 31.108 & \\
\cline { 2 - 5 } & Residual & 12.977 & 66 & 0.197 & & \\
\cline { 2 - 5 } & Total & 106.300 & 69 & & & \\
\hline
\end{tabular}

The accumulation of $\mathrm{R}^{2}$ value in the three steps of regression showed dramatic increase in adjusted $\mathrm{R}^{2}$ value. Satisfaction with privacy (the strongest predictor of OWS) has explained more than $76.5 \%$ of overall workplace satisfaction. This could be mainly due to the high correlation between satisfaction with privacy and other aspects of workplace satisfaction. Table 5 explains this clearly when Pearson correlation was performed, satisfaction with privacy was found to be strongly correlated with all other eight aspects of workplace satisfaction. This also explains that employees perceive their need for privacy in different forms. The required privacy obtained from minimum workspace area, minimum level of noise, minimum level of proximity to coworkers, and so on. Moreover, employees have perceived privacy obtained from being adjacent to external wall rather than in the middle of workplace plan, as this affects satisfaction with natural lighting.

The sum of adjusted $\mathrm{R}^{2}$ in regression when satisfaction with services (the second strongest predictors) was entered has raised it to $84.0 \%$, and to 87.2 once satisfaction with workspace area (the third strongest predictor) was entered. Both satisfaction with services and with workspace area were also found to be highly correlated with almost all other aspects of workplace satisfaction. Moreover, satisfaction with services was found to be highly correlated with Staff/room ratio and parking/staff ratio. 


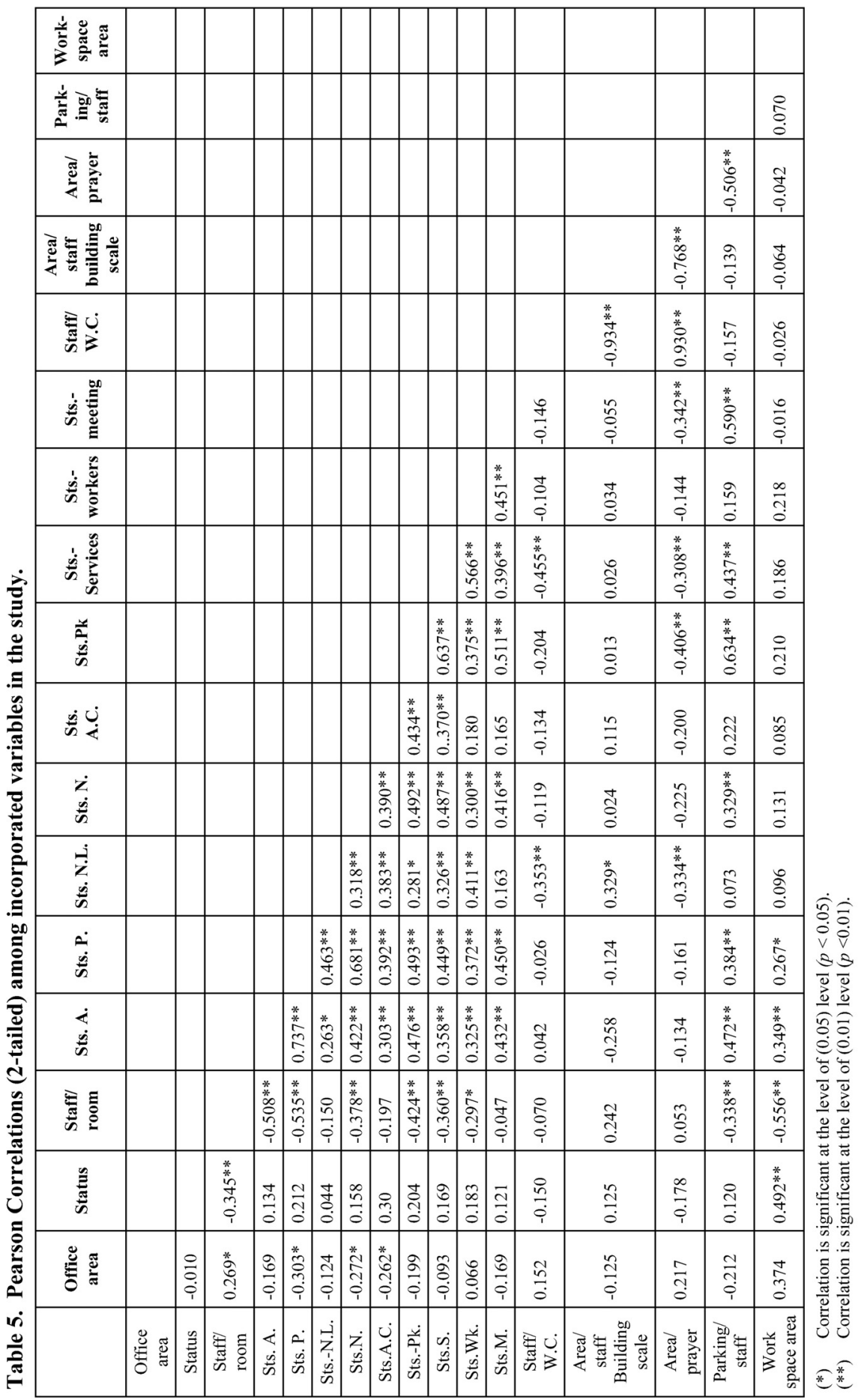


Table 6 supports research findings, which shows employees reaction about the importance of satisfaction with the nine adopted aspects of workplace design on the level of their productivity. Satisfaction with privacy has scored $4.80 / 5$, satisfaction with services $4.53 / 5$, and with workspace area $4.13 / 5$. Other important factors of productivity were air conditioning and availability of parking spaces. Moreover, when employees were asked about their satisfaction with the level of productivity in workplaces, results were always close to their response to OWS. This means employees' perception of productivity is almost similar to their perception of OWS.

These results support what Pam Brenner came up with. He found both office space and privacy were related to work efficiency (Eisinger, 2002). The results also support Kupritz findings where workspace, services including equipments, and privacy where found to be productivity-aiding factors.

Table 6. Employees' reaction towards the importance of satisfaction with adopted aspects of workplace environment on productivity.

\begin{tabular}{|c|c|c|c|c|c|c|c|c|c|c|}
\hline B & $\mathbf{G}$ & $\begin{array}{c}\text { Sts. } \\
\text { A. } \\
\end{array}$ & $\begin{array}{c}\text { Sts. } \\
\text { P. }\end{array}$ & $\begin{array}{l}\text { Sts. } \\
\text { N.L. }\end{array}$ & $\begin{array}{c}\text { Sts. } \\
\text { N. }\end{array}$ & $\begin{array}{l}\text { Sta. } \\
\text { A.C. }\end{array}$ & $\begin{array}{l}\text { Sts. } \\
\text { Pk. }\end{array}$ & $\begin{array}{c}\text { Sts. } \\
\text { S. }\end{array}$ & $\begin{array}{c}\text { Sts. } \\
\text { Wrk. }\end{array}$ & $\begin{array}{l}\text { Sts. } \\
\text { M. }\end{array}$ \\
\hline \multirow[t]{3}{*}{1} & $\mathrm{~S}$ & 4 & 4 & 3 & 4 & 5 & 5 & 5 & 4 & 3 \\
\hline & $\mathrm{A}$ & 4 & 5 & 3 & 4 & 5 & 5 & 5 & 4 & 3 \\
\hline & $M$ & 4 & 5 & 4 & 5 & 5 & 5 & 4 & 3 & 3 \\
\hline \multirow[t]{3}{*}{2} & $\mathrm{~S}$ & 5 & 5 & 3 & 5 & 5 & 5 & 4 & 4 & 3 \\
\hline & A & 5 & 5 & 3 & 5 & 5 & 4 & 4 & 5 & 3 \\
\hline & $M$ & 4 & 5 & 3 & 5 & 5 & 5 & 5 & 3 & 4 \\
\hline \multirow[t]{3}{*}{3} & $\mathrm{~S}$ & 5 & 5 & 3 & 5 & 4 & 5 & 4 & 4 & 4 \\
\hline & $\mathrm{A}$ & 4 & 5 & 3 & 5 & 5 & 5 & 5 & 5 & 5 \\
\hline & $\mathrm{M}$ & 4 & 5 & 4 & 4 & 5 & 5 & 4 & 3 & 3 \\
\hline \multirow[t]{3}{*}{4} & $\mathrm{~S}$ & 4 & 4 & 3 & 4 & 5 & 4 & 5 & 4 & 3 \\
\hline & $\mathrm{A}$ & 3 & 4 & 3 & 4 & 5 & 5 & 5 & 4 & 4 \\
\hline & $\mathrm{M}$ & 4 & 5 & 5 & 4 & 5 & 5 & 5 & 3 & 5 \\
\hline \multirow[t]{3}{*}{5} & $\mathrm{~S}$ & 4 & 5 & 3 & 5 & 5 & 5 & 5 & 3 & 4 \\
\hline & A & 4 & 5 & 3 & 5 & 5 & 5 & 4 & 4 & 3 \\
\hline & $\mathrm{M}$ & 4 & 5 & 5 & 5 & 5 & 5 & 4 & 3 & 5 \\
\hline \multicolumn{2}{|c|}{ Av. } & 4.13 & 4.8 & 3.4 & 4.6 & 4.9 & 4.86 & 4.53 & 3.73 & 3.66 \\
\hline
\end{tabular}

1=Absolutely not important, 2=Not important, 3=Has no impact, 4=Important, 5=Absolutely very important. $\mathrm{S}=$ Secretaries, $\mathrm{A}=$ Administrators, $\mathrm{M}=$ Managers

\section{Conclusion}

This study has revealed employees' satisfaction towards nine aspects of physical environment in five rented Saudi workplaces which 
belong to Municipality of Holy Makkah. Results showed dissatisfaction with some aspects of workplace environment. The dissatisfaction was summarized in three levels: (1) high dissatisfaction with quality of services and level of noise; (2) medium dissatisfaction with availability of parking space and level of informal meetings among staff; and (3) low dissatisfaction with level of privacy, quality of air conditioning, proximity with co-workers, and workspace area. The paper suggested some workplace standards in order to raise employees' level of satisfaction.

The paper also identified the strongest predictors of overall workplace satisfaction OWS. These were ,satisfaction with privacy, satisfaction with services, and satisfaction with workspace area. The three predictors of overall workplace satisfaction (OWS) were strongly considered by employees as important factors related to their productivity.

\section{References}

[1] Sunstrom, E., Workplaces, The Psychology of the Physical Environment in Offices and Factories, Cambridge University Press (1986).

[2] Duffy, F., Office Design and Organization: 2-Testing of Hypothetical Model, Environment and Planning, 1: 217-235 (1974).

[3] Bussel, A., On the Sunny Side of Street: Nonterritorial Corporate Offices Are Back. But Why? Architecture, 91(8): 37-40 (2002).

[4] Cuneo, A., Kovel Kresser\& Partners' Symbiotic Office in Venice, Calif., Advertising Age, 69(16): 42 (1998).

[5] Tom, K., Trends in Office Design, Interiors \& Sources, 12(2): 53-4 (2005).

[6] Luparello, D., Office Design Trends, Interiors \& Sources, 12(7): 20-1 (2005).

[7] Timm, D., Making Ergonomic Adjustment to the Workplace, Buildings, 101(5): 32 (2007).

[8] Prospero, M., Space Shot: You Wish You Work Here: Genzyme Center, Fast Company, 115: 108-11 (2007).

[9] Sterk, K., Getting a Rise Out of Productivity, Buildings, 99(7): 72,74,76,78 (2005).

[10] Eisinger, J., The Optimal Office, Association Management, 54(10): 56-60, 62,109 (2002).

[11] Kupritz, V., Workplace Design Compatibility for Today's Aging Worker, Journal of Industrial Teacher Education, 36(3): 53-69 (1999). 


\section{بيئة أماكن العمل ومعدل الإنتاجية: انطباع الموظفين نحو البيئة الفيزيائية في المباني الإدارية المستأجرة في المملكة العربية السعودية}

\section{عادل محمد أحمد بن ياسين}

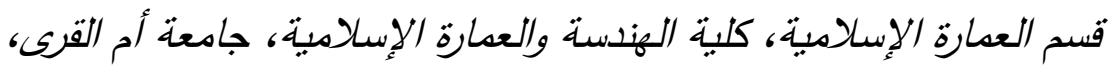

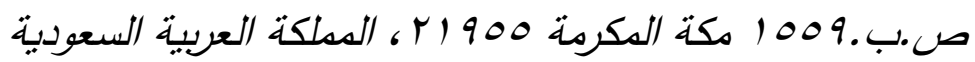

Binyaseen@yahoo.com

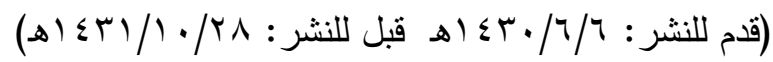

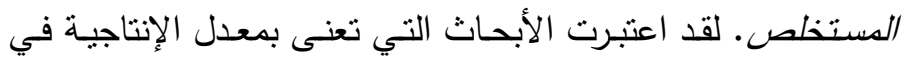

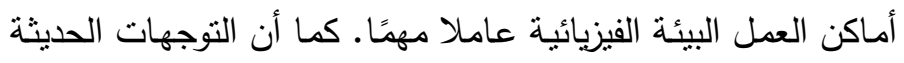

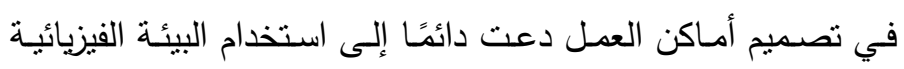

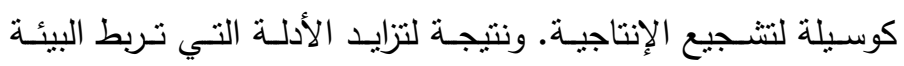

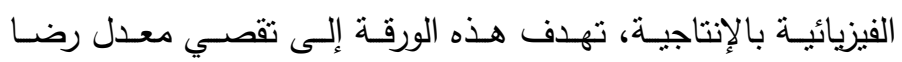

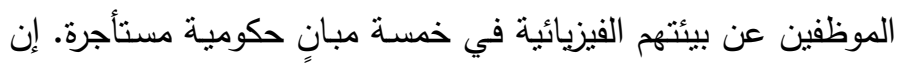

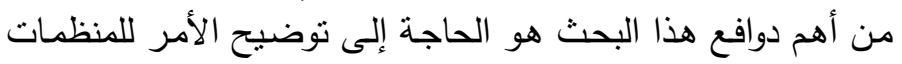

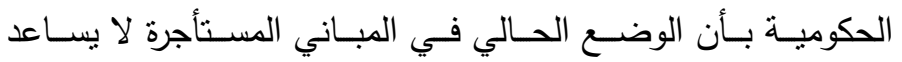

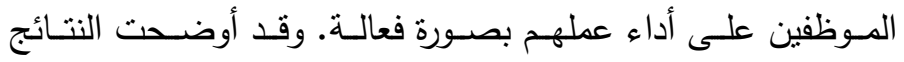

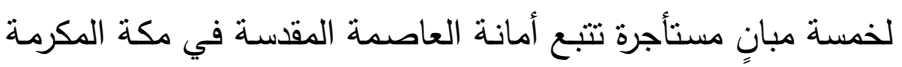

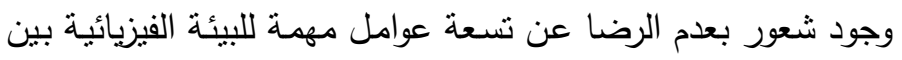

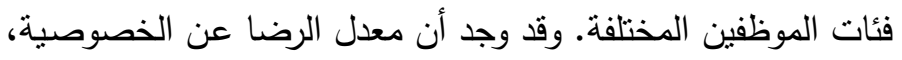

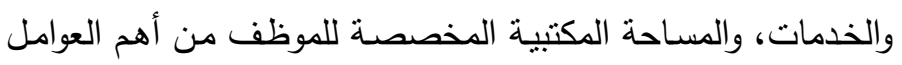

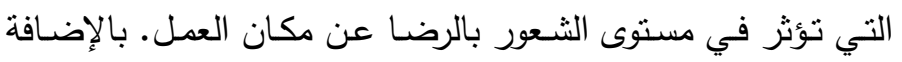

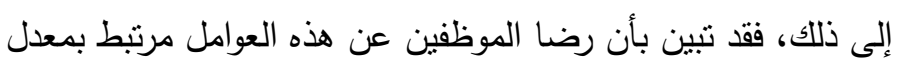
الإنتاجية ارتباطا وثيقا. 